\title{
The Tajikistan Project: Energy for Education
}

\author{
Hubert Stinia ${ }^{1 *}$, Joanna Maraszek $^{1}$, Anna Ścierska ${ }^{1}$, Muhammadjon Odinabekov ${ }^{2}$, Dilshod \\ Rajabov $^{2}$, Dlinoza Nabieva ${ }^{2}$, Gulnora Anvarova ${ }^{2}$, Magdalena Dudek $^{1}$, Andrzej Raźniak ${ }^{1}$, and \\ Paulina Szpyt ${ }^{1}$ \\ ${ }^{1}$ AGH University of Science and Technology, Department of Energy and Fuels, Krakow Poland \\ ${ }^{2}$ Tajik Technical University named after academic M.S.Osimi, Department of Power Engineering, \\ Dushanbe Tajikistan
}

\begin{abstract}
This paper presents the main results of a project aimed at developing educational materials (lectures, laboratory exercises, and elearning materials) in the field of renewable and hydrogen energy for the students of the Tajik Technical University. Special emphasis was placed on the exchange of knowledge and experience with respect to scientific achievement and education in renewable energy and energy storage technologies. The design and construction of a special educational installation of off-grid distributed power systems designed for the practice of exercises is described. An autonomous solar lamp system powered by PV solar panels is described in operation under in-field conditions. The laboratory setup consisted of $150 \mathrm{~W}$ photovoltaic solar panels, an accumulator-type battery, an electronic charge monitoring system, and a Raspberry Pi microcomputer, enabling the real-time monitoring of PV system parameters (measurement of the voltage, current, and power generated by PV panels) as well as the archiving of data transmitted via the internet to the SQL database.
\end{abstract}

\section{The energy sector in Tajikistan}

Tajikistan is a mountainous country; over $93 \%$ of its area is covered by mountains, in particular the Pamir range. Tajikistan is bordered by Afghanistan to the south, China to the east, and Kyrgyzstan and Uzbekistan to the north and west, respectively. The country is inhabited by over 8.4 million people, with an area of about $143,000 \mathrm{~km}^{2}$ and a resulting population density of about 50 people per $\mathrm{m}^{2}$. Water resources in Tajikistan are significant. The potential for annual energy production is estimated at 527 billion kilowatt hours $(\mathrm{kWh})$; in terms of technical potential, this figure is approximately 317 billion $\mathrm{kWh}$, or $60 \%$, per year. This places Tajikistan in eighth place overall in the world, as well as second in electricity per capita and first in hydropower potential [1-3].

The specific nature of the terrain causes many infrastructural problems. Many villages, especially in the Pamir area, are cut off from access to electricity and even water. Another problem is inequality between the country's regions: the economically developed north has difficulty extending the electric grid to the poorly-developed south, where the best conditions prevail for the construction of large hydroelectric power plants capable of meeting the entire

\footnotetext{
*Corresponding author: huberts@student.agh.edu.pl
} 
country's demand for energy. Especially in southern Tajikistan, numerous rivers, well suited, as a rule, for the construction of small and medium hydropower plants, are characterised by marked declines in flow rates during the summer months. At present, $95 \%$ of the country's electricity is obtained from large hydropower plants. Due to the freezing of rivers in the winter months, energy production drops drastically during the time when demand is the highest. This strongly affects the country's economy. According to estimates, 1 of 7 people have very limited access to electricity, or none.

Tajikistan produced 17.3 GWh of electricity in 2017. Consumption by particular sectors is shown in Fig. 1.

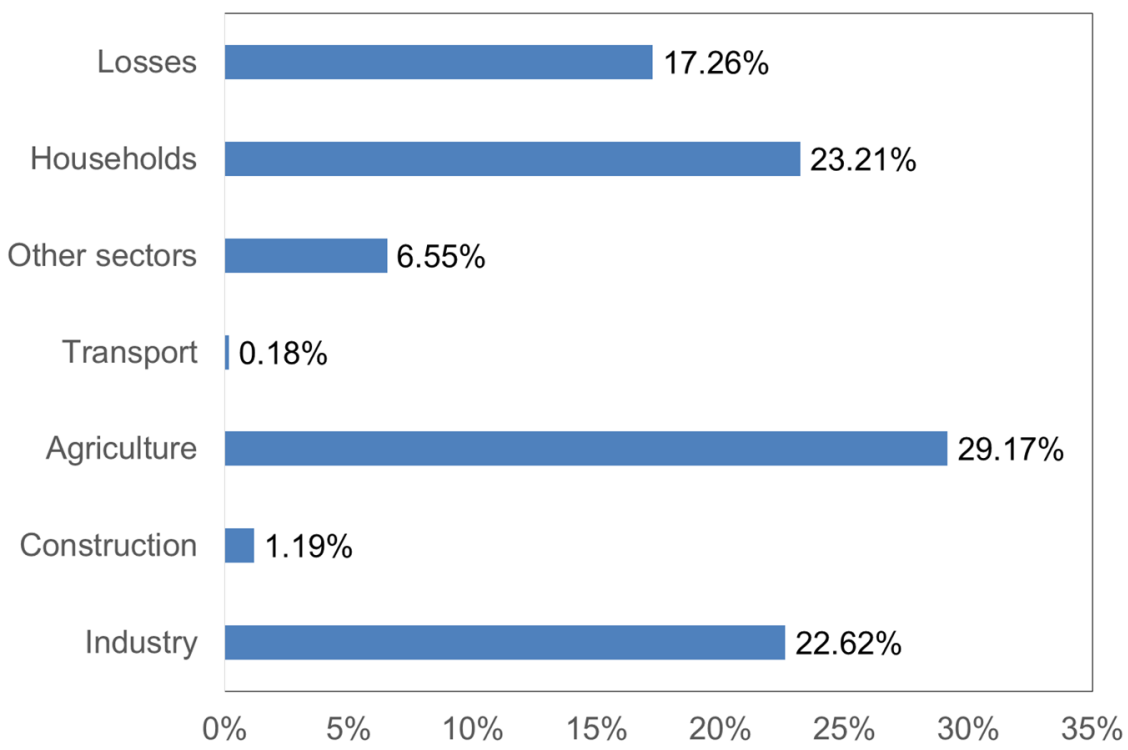

Fig. 1. Participation in electricity consumption by sectors in 2017 [4]

The largest hydroelectric plant currently in operation is the Nurek 3,000-MW hydropower plant, with maximum power equal to $60 \%$ of the installed capacity of the whole country. Due to changes in river flow rates and energy demand, only 53-68\%, on average, of the installed capacity is used. The greatest problems arise during the winter months, during which the maximum energy supply is estimated at 2,250 MW, which covers only $47 \%$ of the demand. This is a particularly serious problem for small hydro plants that are not equipped with reservoirs capable of storing water; as a result, their ability to produce energy drops by $75 \%$. In winter, the energy supply gap is $24 \%$, which is equivalent to economic losses estimated at $\$ 200$ million [5]. Air pollution resulting from burning low-quality wood and coal to heat households or cook meals represents an immediate threat to the lives and health of residents. Residents of rural areas choose biomass as fuel, partly due to the price of electricity, which, despite being among the lowest in Central Asia (US 1.9 cents/kWh) [6], nonetheless represents between 10 to $24 \%$ [6] of monthly income for $70 \%$ of the country's population. This is not improved by either the poor state of the infrastructure, which causes high energy losses, or very energy-intensive aluminium production by one of the largest Tajik companies, TALCO. One potential solution to these problems is represented by the government's efforts in Tajikistan to improve existing power plants and build new ones. The most important project is the construction of the Rogun hydropower plant, with a planned capacity of 3,600 MW, which would satisfy domestic demand as well as enabling energy exports to other countries. What is more, Rogun, like Nurek, will be used not only to produce energy but also to store water for irrigation. It should be noted that the construction of such a large power plant is a geopolitical project that affects the local and international community as well as the 
natural environment. The government of Uzbekistan, which borders on Tajikistan and is located downstream of the rivers flowing through the country, is concerned that the construction of the dam will cause further drying of the Aral Sea; this will exacerbate problems in the region, leading to drought which, in turn, may cause losses estimated at $\$ 600$ million per year [7]. Irrespective of these problems, the first turbine is expected to be activated in November 2018. Another area for development in Tajikistan is a solution promoted by the United Nations, emphasising the use of renewable energy sources and improvement of energy efficiency, according to which priority should be given to small hydropower plants and solar energy, both thermal and photovoltaic [8]. The latter form is capable of constituting the basis of this programme, by virtue of such factors as a high rate of solar exposure and the proximity of China, a solar technology leader, thanks to which cheap, high-quality devices can be provided. Therefore, we decided to introduce students to the field of renewable energy. In the project we followed this idea, starting with the promotion of Sustainable Development Goals - primarily three: affordable and clean energy, quality education, and partnerships for the goals.

\section{Renewable energy in Poland}

In 2017, the generation capacity of the Public Power System (PPS) in Poland equalled $43.5 \mathrm{GW}$, with an average annual demand of $22.9 \mathrm{GW}$ and a maximum demand of $26.2 \mathrm{GW}$. In 2017, the annual generation of PPS electricity amounted to $170.1 \mathrm{TWh}$, most of which was derived from the combustion of fossil fuels - coal-fired power plants $(50 \%)$, lignite-fired power plants $(30 \%)$, and gas-fired power plants $(6 \%)$ - due to Poland's possession of substantial coal reserves. The remaining $14 \%$ was derived from renewable energy sources (RES), the main sources being wind farms $(7 \%)$, biofuels and waste $(6 \%)$, and water turbine plants $(1 \%)$. In Poland, wind farms $(5.8 \mathrm{GW})$ predominate in terms of RES generation capacity, followed by water turbine plants $(1 \mathrm{GW})$, biomass sources $(0.9 \mathrm{GW})$, biogas plants $(0.2 \mathrm{GW})$, and solar cells $(0.2 \mathrm{GW})$ [9-12].

The share of RES in electricity generation, which is growing consistently every year, is expected in 2020 to reach the target of $15 \%$ of RES set for Poland with regard to the fulfilment of its European Union obligations resulting from the directive of the European Parliament and the Council of 23 April 2009 (2009/28/EC) aimed at reducing $\mathrm{CO}_{2}$ emissions. In the generation of RES electricity, the dominant share is currently held by large wind farms characterised by increasingly large turbines with capacities of several MW, which, due to their size and prevailing wind conditions, are being planned with increasing frequency for installation at sea (offshore). The capacities of such renewable sources as water, biogas, and biomass have been maintained virtually unchanged for years. As a result of a new law on renewable energy sources and a significant price decrease in the photovoltaic market, a dynamic increase in electricity generation from solar energy is being observed (a 110-fold increase in the amount of electricity generated by PV since 2012). The dynamic growth of PV systems is possible due to the aforementioned new law, which introduced the concept of prosumers, owners of PV micro systems with capacities of up to $10 \mathrm{~kW}$ who generate energy from renewable sources for their own use. These are on-grid installations with capacities of up to $10 \mathrm{~kW}$, working in tandem with the power system, which serves them as a form of energy storage, such that, when prosumers are low on electricity, they can recover up to $80 \%$ from the power grid free of charge for each $1 \mathrm{kWh}$ of electricity sent to the grid. This has resulted in the increased popularity of new domestic photovoltaic micro power plants and their installation on a large scale in Poland [9-13]. 


\section{Electricity storage in hydrogen}

Electricity storage is not only an important element of the market approach to balancing the demand for and supply of electricity while ensuring the reliability of the latter. As an element of the so-called 'smart grid', it is also an important component supplementing a distributed network of renewable energy sources, which is subject to unstable operation due to changing weather conditions. Electricity can also be stored in the form of chemical energy of fuel. This technology takes electricity from renewable sources or energy production surpluses and uses it to produce hydrogen by electrolysis. This process takes place mainly in polymeric or alkaline electrolytic cells. The high-purity hydrogen obtained by means of this technology can subsequently be used as a raw material for power-to-gas or power-to-liquid synthesis, or for the production of electricity. Currently, many countries, both in the EU and worldwide, are emphasising the development of their hydrogen economy, which encompasses three concepts: hydrogen production, storage, and use in the fuel and energy sector $[14,15]$.

It is worth mentioning that hydrogen, as an energy carrier, is still seeking social acceptance. Undoubtedly, the main reason for this is its bad reputation in the past. The Hindenburg disaster still inclines people to doubt that hydrogen can be an ecological and safe fuel or a reliable energy carrier. Despite the zeppelin's careful construction and the extensive experience of the Germans in the use of hydrogen, in May 1937, while the ship was being moored at an airport in Lakehurst, NJ, USA, a fire broke out, most likely caused by a discharge between the airship sheathing and the mooring tower. Thirteen passengers and 22 crew members were killed [16]. After many years of research, it was found that the cause of the crash was not hydrogen but an unfortunate coincidence related to the construction of the airship.

Another spectacular example of a hydrogen-related disaster was the explosion of the Challenger space shuttle in 1986. The cause of the accident was damage to the sealing ring in the booster engine, and a sequence of subsequent events leading to the ignition of the external fuel tank and the destruction of the shuttle. Although the cause of the crash was a failure of an engine component, the image of the fuel explosion remained in the public consciousness [17].

The hydrogen-related accidents described above distort the public perception, according to which it is a dangerous fuel. The question now is whether it is more dangerous than other fuels already in widespread use, and whether we as a society should change the way we think about hydrogen. It should be emphasised that the use of currently popular fuels such as natural gas, gasoline, diesel oil, or coal also poses hazards.

The implementation of renewable energy technology in connection with hydrogen technologies requires action at various levels to create not only a hydrogen infrastructure similar to those existing for liquid fuels, but also an integrated energy development system encompassing, along with safety improvements, research and development, and hydrogen use safety, the development of specialised teaching materials for university students and engineering staff and for primary and secondary school students alike [18].

This challenge was taken up in the Tajik project. This paper presents the main results of a project aimed at developing educational materials (lectures, laboratory exercises, and elearning materials) in the field of renewable and hydrogen energy for students at the Tajik Technical University.

\section{Online monitoring of a solar-powered LED lamp system}

To promote the acquisition of practical skills in the field of renewable energy, a 'solar lamp' test stand was built, consisting of a LED lamp powered by a battery which could be 
recharged with electricity generated by photovoltaic panels. Fig. 2 presents an electrical diagram of the LED lamp system, powered by electricity generated by photovoltaic panels, with a monitoring system.

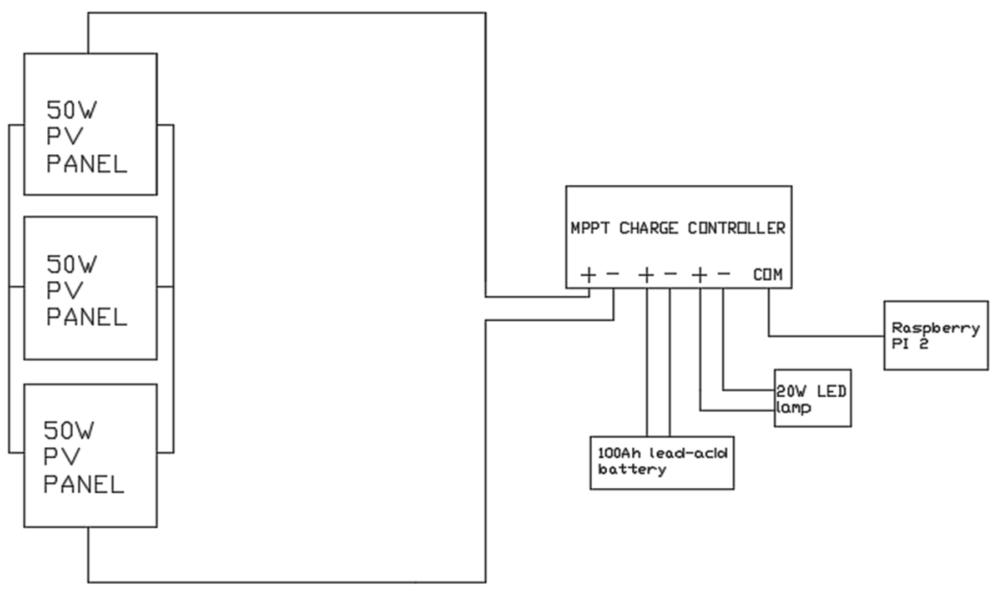

Fig 2. Electrical diagram of an online monitoring system for an LED lamp powered by solar energy from a photovoltaic panel

Table 1 presents the main devices necessary to construct this LED lamp system.

Table 1. List of components of an online monitoring system for an LED lamp powered by solar energy from a photovoltaic panel

\begin{tabular}{|l|l|l|}
\hline Device & Technical description/model & Quantity \\
\hline Photovoltaic panel & 4SUN-FLEX-M 50W & $3 \mathrm{pcs}$ \\
\hline Charge controller & EPSolar Tracer 2210A (MPPT) & $1 \mathrm{pc}$ \\
\hline Lamp & LED 20W IP65 & $1 \mathrm{pc}$ \\
\hline Battery & $\begin{array}{l}\text { 100-Ah 'REACTOR' 1000 } \\
\text { lead-acid }\end{array}$ & $1 \mathrm{pc}$ \\
\hline Microcomputer & Raspberry PI 2B & $1 \mathrm{pc}$ \\
\hline
\end{tabular}

Table 2. Electrical parameters of the three photovoltaic panels (4SUN-FLEX-M 50W) connected in parallel

\begin{tabular}{|l|l|}
\hline Optimal power $\left[\mathrm{P}_{\max }\right]$ & $145.8 \mathrm{~W}$ \\
\hline Working voltage $\left[\mathrm{V}_{\mathrm{mp}}\right]$ & $18 \mathrm{~V}$ \\
\hline Working current $\left[\mathrm{Imp}_{\mathrm{mp}}\right]$ & $8.1 \mathrm{~A}$ \\
\hline Short-circuit current $[\mathrm{Isc}]$ & $8.7 \mathrm{~A}$ \\
\hline Open-circuit voltage $[\mathrm{Voc}]$ & $20 \mathrm{~V}$ \\
\hline
\end{tabular}


Table 2 presents the electrical parameters of the three 4SUN-FLEX-M 50W photovoltaic panels used to construct the investigated setup.

As can be seen in Fig. 2, the LED lamp was powered by a battery via an EPSolar Tracer 2210A (MPPT) charge controller, which controlled recharging of the battery from the photovoltaic panels. Thanks to the RS-485 communication port in the controller, it was possible to design an online monitoring system based on the Raspberry PI 2B microcomputer, which was selected on the basis of its sufficient computing power, small size, and energy requirements (so-called auxiliaries).

The current and voltage values of the photovoltaic panels measured by the charge controller were sent via the RS-485 communication port to the Raspberry PI microcomputer. Then, processed data was sent every minute via the Internet to the MySQL database located on the AGH University of Science and Technology server. There, the data was acquired, monitored, and presented on a website.

\section{Hydrogen from the electrolyser powered by photovoltaic panels}

Another important stage was the education of students in the field of hydrogen technology. The construction of a research station consisting of a Kyocera 80-W photovoltaic panel and an E107 electrolytic cell (H-TEC, Germany) was a satisfactory solution. The versatility of this set enabled work to be carried out in both natural and artificial lighting.

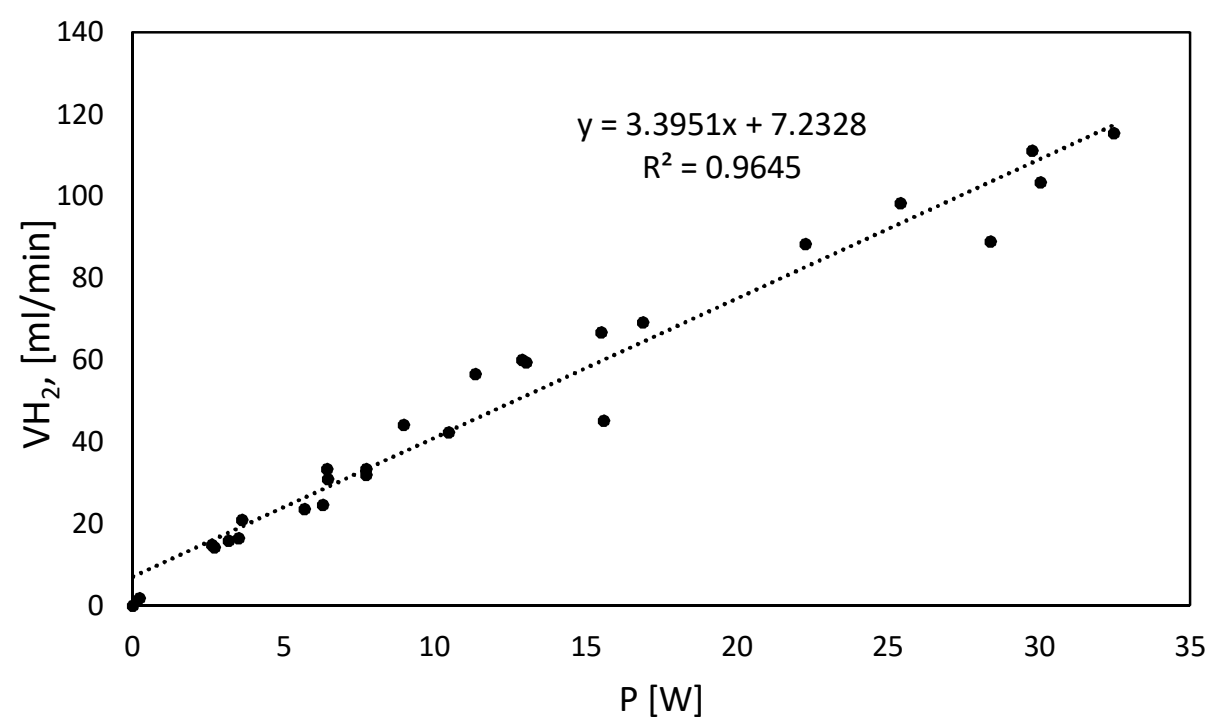

Fig. 3. Dependence of variation in the amount of hydrogen produced by the electrolyser from power supplied from the photovoltaic panel

Fig. 3 presents the dependence of variation in the amount of hydrogen produced by the electrolyser from power supplied from the photovoltaic panel. The same figure shows that the amount of hydrogen produced increases linearly with the amount of supplied electrical power $(\mathrm{P})$. 


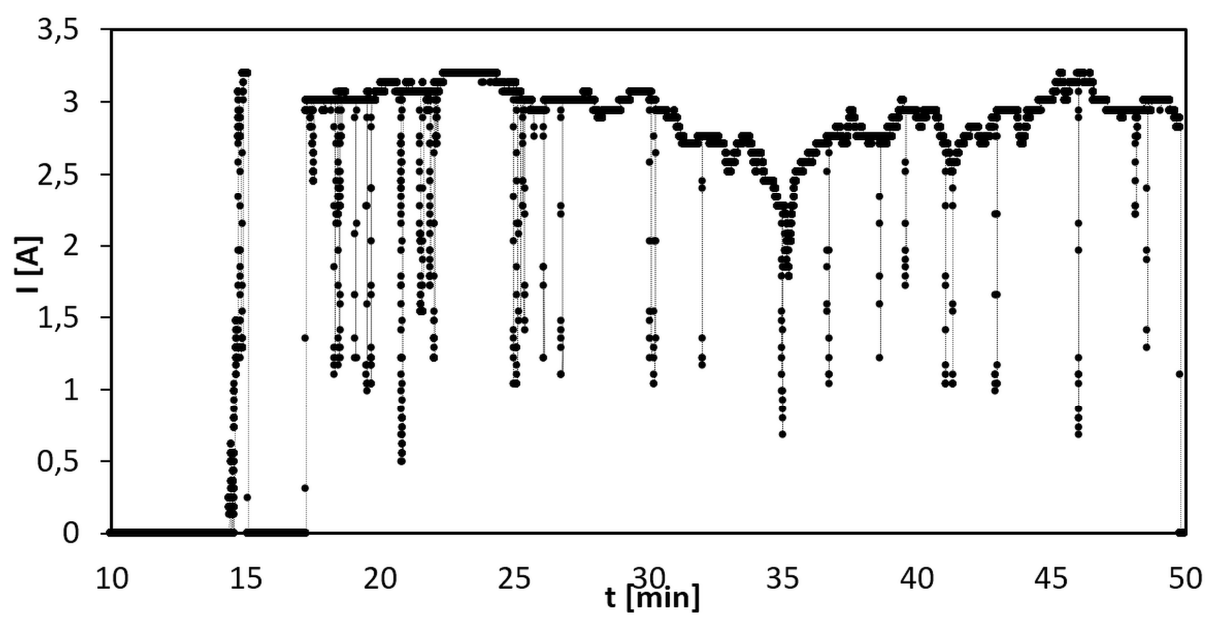

Fig. 4. Dependence of variation in the intensity of the electrolysis current (I) generated by the photovoltaic panel under natural lighting conditions

Fig. 4. presents the dependence of variation in the intensity of the electrolysis current (I) generated by the photovoltaic panel under natural lighting conditions. The changes observed in the intensity of the current (I) generated by the photovoltaic panel are the result of changes in atmospheric conditions, mainly exposure to sunlight, during the experiment. Fig. 3. shows how variations in exposure to sunlight adversely affect the production of electrical power, which in turn directly affects the limited efficiency of the electrolytic cell. The experiments presented in Fig. 3. and Fig. 4. indicate the necessity to install either electrical power equipment to stabilise the electrolytic cell or a buffer energy source in the form of a battery and a supercapacitor cell, making it possible to safely intensify and stabilise the production of hydrogen from the electrolytic cell. Despite fluctuations, the average current was around $2 \mathrm{~A}$; it was possible to produce $5.7 \mathrm{Ndm}^{3} \mathrm{H}_{2}$ of hydrogen despite partially cloudy conditions.

\section{Conclusion}

The Tajikistan project was a unique initiative of co-operation between universities in Poland and Tajikistan. The most important educational goal of the project was achieved. Tajik students shared knowledge about renewable energy sources with their younger colleagues and then taught other students and children from schools in Dushanbe and other cities. Undoubtedly the educational setups used in the projects played a very important role during classes and enabled students and pupils to acquire practical skills. This project unquestionably facilitated scientific co-operation between the AGH University of Science and Technology and the Tajik Technical University in new areas of science, not only those related to renewable energy. In today's world, the international exchange of knowledge and experience serves as a basis for development - above all, sustainable development.

Acknowledgement: This work was supported by AGH UST Rector Grant 


\section{References}

1. IRENA Renewable Energy and Jobs Annual Review Abu Dhabi (2018)

2. EDB. Water and Energy Resources in Central Asia: Utilization and Development Issues (Industry Report). Strategy and Research Department of the Eurasian Development Bank, Almaty, Kazakhstan (2008)

3. K Fakirov, Tajikistan - Rapid Assessment and Gap Analysis (SE4ALL). Interdepartmental working group established by the Ministry of Economic Development and Trade, Dushanbe, Tajikistan (2012).

4. Statistical Agency under President of the Republic of Tajikistan http://stat.ww.tj/library/en/table_11.xls (accessed 10.08.2018)

5. D. Fields, A. Kochnakyan, T. Mukhamedova, G. Stuggins, J. Besant-Jones, Tajikistan's Winter Energy Crisis: Electricity Supply and Demand Alternatives (World Bank Study). (World Bank, Washington, D.C , 2013)

6. R. Swinkels, Assessment of Household Energy Deprivation in Tajikistan: Policy Options for Socially Responsible Reform in the Energy Sector (No. 88837) (The World Bank 2014)

7. S.-M. Jalilov, T.M. DeSutter, J.A. Leitch, Impact of Rogun dam on downstream Uzbekistan agriculture. Int. J. Water Resour. Environ. Eng. 3, 161-166 (2011)

8. Z. Morvaj, V. Bukarica, N. Cupin, D. Gvozdenac, O. Markovic, S. Robic, Intermediate Strategy for Renewable Energy Sources Based Integrated Rural Development. (UNDP, Dushanbe, Tajikistan 2010)

9. PPS Quantitative Data Summary for 2017 https://www.pse.pl/danesystemowe/funkcjonowanie-rb/raporty-roczne-z-funkcjonowania-kse-za-rok/raportyza-rok-2017\#t1_1 (access 2018.10.16)

10. https://old.ure.gov.pl/old/rynki-energii/energia-elektryczna/charakterystykarynku/7562,2017.htm (access 2018.10.16)

11. Central Statistical Office Energy from Renewable Sources in 2016 http://stat.gov.pl/obszary-tematyczne/srodowisko-energia/energia/energia-ze-zrodelodnawialnych-w-2016-roku,3,11.html (access 2018.10.16)

12. The Energy Regulatory Office of Poland, https://www.ure.gov.pl/pl/rynkienergii/energia-elektryczna/odnawialne-zrodla-ener/potencjal-krajowy-oze/5753,Moczainstalowana-MW.html (access 2018.10.16)

13. https://www.ure.gov.pl/download/1/9394/MoczainstalowanaMWwgstanuna30062018r. pdf (access 2018.10.16)

14. R. Moliner, M. J. Lázaro, I. Suelves, Analysis of the strategies for bridging the gap towards the Hydrogen Economy, Int. J. Hydrog. Energy 41, 19500-19508 (2016)

15 M. Pudukudy, Z. Yaakob, M. Mohammad, B. Narayanan, K. Sopian, Renewable hydrogen economy in Asia - Opportunities and challenges: An overview, Renew. Sust. Energ. Rev 30, 743-757 (2014)

16. C. E. (Sandy) Thomas, A Review of Hindenburg: Exploring The Truth, by Addison Bain, Int. J. Hydrog. Energy 40, 752 (2015)

17. H. J. Pasman, W. J. Rogers, Safety challenges in view of the upcoming hydrogen economy: An overview, J. Loss. Prev. Process. Ind, 23, 697-704 (2010)

18 K. Alanne, A survey of Finnish energy engineering students' knowledge and perception of hydrogen technology, , Int. J. Hydrog. Energy 43, 10205-10214 (2018) 